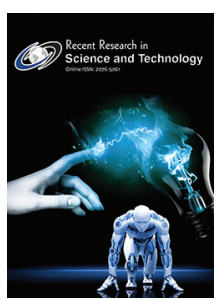

ISSN: 2076-5061
Received: December 16, 2018 Accepted: February 01, 2019 Published: February 11, 2019

*Corresponding Author: Manjur Shah

Email:mmanjurshah@gmail. com

\section{Redescription of Lepismatophila cruszi Kundu and Haldar, 1984 (Apicomplexa: Sporozoea) from Chondracis rosea (Order: Orthoptera)}

\author{
Indira Yumnam', N. Mohilal', M. Manjur Shah²* \\ 'Parasitology Section, Department of Life Sciences, Manipur University Canchipur- 795003, Manipur, ${ }^{2}$ Department \\ of Biological Sciences, Yusuf Maitama Sule University, Kano, Nigeria
}

\section{ABSTRACT}

This study describes external characteristics and life history of a species of cephaline gregarine (Apicomplexa: Sporozoea) of the genus Lepismatophila [1], from Chondracis rosea (Order: Orthoptera) of Manipur, India. Diagnosis characteristic of the species the epimerite a simple symmetrical knob, Protomerite present throughout trophozoite stage, Solitary nature of Sporadins, Cyst without ducts dehiscence by simple rupture and Spores in uncoiling chains, ellipsoidal, boat shaped, without any filamentous process are discussed. And the morphological details of the different stages supported with photomicrographs are also provided.

KEYWORDS: Cephaline gregarine, Lepismatophilacruszi, Manipur, India

\section{INTRODUCTION}

The genus Lepismatophila was established by Adams and Travis [1], described Lepismatophila thermobiae as the type species of the genus, obtained from the firebrat, Thermobia domestica (Pack.). The characteristic features of the genus as proposed were solitary Sporadins, Epimerite a simple symmetrical knob, Protomerite present throughout different stage, Cyst dehiscing by simple rupture and Spores in uncoiling chains, ellipsoidal, devoid of processes. Later on many workers [2-6] described many new species under the genus from various locations. However, later on studies by Kundu and Haldar [7] on the cephaline gregarine yielded a parasite from the common Silver-fish of the Gangetic plain and named it as L. cruszi.

In the present investigation, the cephaline gregarine obtained from Chondracis rosea (Order: Orthoptera) collected from Kajipat, Imphal-east, Manipur was found to be Lepismatophila cruszi and redescribed.

\section{MATTERIALS AND METHODS}

The samples were collected from various grass fields of Manipur as explained previously [11] and prepared for the study [8]. Gametocysts were recovered from the hind gut and placed in moist chambers (80\% relative humidity) for sporulation [9].
The previously reported procedure [11] was followed throughout the study. Nomenclature for shapes used in this paper conforms to those of Clopton [10].

\section{RESULT}

\section{Trophozoite}

The detailed structures of a trophozoite measures 35.9-149.0 (82.8 \pm 25.8$) \mu \mathrm{m}$. The body as usual bears epimerite, prortomerite and deutomerite. The epimerite is petalloid or has two horned structure that pushes through the host epithelium. The protomerite is sub-conical or hemispherical in shape, measures 6.4-24.0 (15.1 55.2) $\mu \mathrm{m} \times 11.7-49.9(28.1 \pm 9.4) \mu \mathrm{m}$. It is followed by the deutomerite and measures 45.0-125.0 (69.5 \pm 25.6$) \mu \mathrm{m} \times 15.0-.54 .0(30.2 \pm 10.2) \mu \mathrm{m}$. It is highly granulated and is separated from the protomerite by a clear septa. The nucleus is circular and measures 12.7-47.0 (20.7 \pm 7.8$) \mu \mathrm{m}$ in diameter, lodged immediately behind the septum, possesses a distinct nuclear membrane and encloses a big endosome and few chromatin granules in it.

\section{Sporadin}

The sporadin are characteristically solitary and are found within the midgut lumen. In living specimens the cytoplasms appear 
milky-white under microscope. The characters of protomerite and deutomerite and the structure of the nucleus are more or less the same as in trophozoites. The only differences is that the pellicle in the sporadins is very thick.

\section{Association}

Typical caudofrontal or frontal associations (Syzygy) are not observed.

\section{Gametocyst}

A freshly collected gametocyst from the hindgut of host is bean shaped with one side convex and the other side slightly concave. The cyst measures $138.8 \times 99.9 \mu \mathrm{m}$. With the gradual development inside the moist chamber, the cyst becomes deep black in colour.

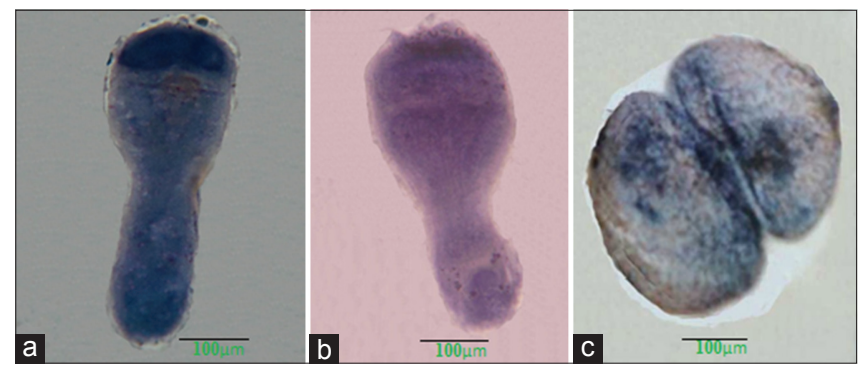

Figure 1: Photomicrographs of Lepismatophila cruszi Adams and Travis, 1935 a - Mature trophozoite, b-Sporadin and c - Gametocyst

Table 1: Showing R, $\bar{X}, S D, S E$ and CV\% of measurement of Lepismatophila cruszi

\begin{tabular}{lccccc}
\hline Different parts & $\mathrm{R}$ & $\overline{\mathrm{X}}$ & $\mathrm{SD}$ & $\mathrm{SE}$ & $\mathrm{CV} \%$ \\
\hline TL & $35.9-149.0$ & 82.8 & 25.3 & 5.65 & 30.7 \\
LP & $6.4-24.0$ & 15.1 & 5.2 & 1.18 & 34.9 \\
WP & $11.7-49.9$ & 28.1 & 9.4 & 2.10 & 33.4 \\
LD & $45.0-125.0$ & 69.5 & 25.6 & 5.74 & 36.8 \\
WD & $15.0-54.0$ & 30.2 & 10.2 & 2.28 & 33.77 \\
LN & $12.0-47.0$ & 20.7 & 7.8 & 1.74 & 37.68 \\
\hline
\end{tabular}

\section{Spore}

Not observed

\section{TAXONOMIC SUMMARY}

$\begin{array}{ll}\text { Material } & : \text { Lepismatophila cruszi Kundu and Haldar, } \\ & 1984 \\ \text { Host } & : \text { Chondracis rosea (Order: Orthoptera) } \\ \text { Locality } & : \text { kajipat, Imphal-east } \\ \text { Site of infection } & : \text { mid gut } \\ \text { Prevalance } & : 50 \text { out of } 100(50.0 \%) \\ \text { Type } & : \text { MU/0217/14, deposited in the Protozoan } \\ & \text { Collection of Parasitology Section, Centre of } \\ & \text { Advanced Studies in Life Sciences, Manipur } \\ & \text { University, Canchipur-795003, India. } \\ & \text { Another Paratype deposited in the National } \\ & \text { Zoological Collection, Zoological Survey } \\ & \text { of India, Kolkata bearing Accession No. } \\ & \text { Pt. 3025. }\end{array}$

\section{Measurements}

Summary of measurements in micrometers of preserved (fixed and stained) Trophozoitesare provided:

Specimen (20): Slide No- MU/0217/14

\section{TROPHOZOITE}

$$
\begin{array}{ll}
\mathrm{TL} & =35.9-149.0(82.8 \pm 25.8) \\
\mathrm{LP} & =6.4-24.0(15.1 \pm 5.2) \\
\mathrm{WP} & =11.7-49.9(28.1 \pm 9.4) \\
\mathrm{LD} & =45.0-125.0(69.5 \pm 25.6) \\
\text { WD } & =15.0-.54 .0(30.2 \pm 10.2) \\
\mathrm{LN} & =12.7-47.0(20.7 \pm 7.8) \\
\text { LP:LT } & =1: 5.6-1: 6.2 \\
\text { WP:WD } & =1: 1.0-1: 1.2
\end{array}
$$

\begin{tabular}{|c|c|c|}
\hline Characters & Lepismatophila Cruszi Kundu and Haldar (1984) & Present specimen \\
\hline Total length & $36.1-150 \mu \mathrm{m}$ & $35.9-149.0 \mu \mathrm{m}$ \\
\hline Epimerite & Petaloid with two- horned measuring 13.7-27.6 $\mu \mathrm{m}$ & Petaloid with two- horned \\
\hline Protomerite & Sub-conical or hemisphere, $17.0-33.7 \mu \mathrm{m}$ & Sub-conical or hemisphere, $6.4-24.0 \mu \mathrm{m}$ \\
\hline Deutomerite & $\begin{array}{l}\text { Highly granulated and is separated from the protomerite by a clear } \\
\text { septa }\end{array}$ & $\begin{array}{l}\text { Highly granulated and is separated from the protomerite by a } \\
\text { clear septa }\end{array}$ \\
\hline Nucleus & Circular in logged & Circular \\
\hline Sporadin & Sporadin are very thick & Sporadin are very thick \\
\hline Gametocyst & Bean-shaped with one convex and the other side is slightly concave & Bean-shaped with one convex and the other side is slightly concave \\
\hline Spore & Boat-shaped with one side is convex & - \\
\hline LP: TL & $1: 2.75-19.0$ & $1: 5.6-1: 6.2$ \\
\hline WP: WD & $1: 0.78-1.33$ & $1: 1.0-1: 1.2$ \\
\hline Host & Acrotelsacollaris (Fabricius) & Chondracis rosea \\
\hline Locality & West-Bengal, India & Kajipat Manipur, India \\
\hline
\end{tabular}

\section{DISCUSSION}

In having solitary sporadins, epimerite a simple-knob and ellipsoidal spores, the gregarines is accommodated in the

Table 2: Showing the comperative characters of Lepismatophila Cruszi 
family Lepismatophilidae. The following characters justify the inclusion of the parasite in the genus Lepismatophila [1].

In the present species the body length of the trophozoite is 35.9-149. $0 \mu \mathrm{m}$. Sporadin are solitary. The fully grown trophozoite as usual bears epimerite, protomerite and deutomerite. The protomerite is sub-conical or hemispherical in shape, epimerite is petalloid or has two horned, deutomerite is highly granulated and is separated from the protomerite by a clear septa. The morphological details and measurements are within the range described in the original work. $50 \%$ of the host examined were infected with the parasite. The characters of the epimerite, structure of the nucleus, the general shape of the protomerite, shape of the cyst and measurement of the different parts of the body are within the range originally described by Kundu and Haldar[7]. But here in the present work spores could not be observed. The cyst development is completed within 96 hrs inside in the moist chamber, have the same dimension as in the eailer described form and the ratio of LP: TL and WP: WD are in the range provided for the described species. Therefore, the presence species is thus considered to be Lepismatophila cruszi and redescribed.

\section{ACKNOWLEDGEMENTS}

The authors are greateful to the Director, Zoological Survey of India, Kolkata for identification for the species and the Head, Department of Life Sciences and Co-ordinator, Centre of Advanced Studies in Life Sciences, Manipur Universityto provide the laboratory facilities and the first author acknowledge the financial assistance provided by Manipur University for Ph.D work.

\section{AUTHOR'S CONTRIBUTION}

The first author conducted the work, the second author planned the work and the third author conducted analysis and presentation of the result.

\section{REFERENCES}

1. Adams, J.A., and Travis, B.V. Two new species of gregarine protozoa from the Firebrat, Thermobia domestica (Pack.) (Thysanura). J. Parasitol.1935;35: 56-59.

2. Bhatia, B. L. Fauna of British India Sporozoa. London. 1938

3. Linday, E.Two gregarines from Ctenlopismalongicandata with notes on forms in other silver. Proc. R. Soc. Vict.1939; 5: 99-11.

4. Tuzet, O., Manier, J.F. and Ormières, R. Deuxnouvellesexpeces de Grégarines de genre Lepismatophila, parasites de I' intestine de Ctenolepismalineata Sch. etx. De Campode Coampodesaugens Silvestri., Ann. Sc. Nat. Zool. 11e. Series. 1952;14: 87-93.

5. Crusz, H.New gregarines parasitic in lepismatids from Ceylon. Proc. Zool. Soc., London, 1960;135:525-536.

6. aschev, D. and Golemnasky, V. (1972).Lepismatophila plusiocampae n. sp. (Gregarinida, Stylocephalidae) - Une nouvelle gregarine de troglobiePlusiocampabureschiSliv. (Diplira, Campodeidae). Zool. Anz., 19072;(5/6): 305-311.

7. Kundu, T.K. and Haldar, D.P. Observations on Quadruhyaiodiscus gallerucidae gen. nov., sp. nov. (Apicomplexa: Sporozoxa) from a chrysomelid beetle, Gallerucida bicelor. Arch. Protistenk. 1984; 128: 327-334.

8. Kudo. Studies on Nyctanthes arbor-tristis Linn. Proc. Indian Sci, Congr Assn. Part III. Candigarh. 1966

9. Sprague, V. Studies on Gregarina blattarum with particular reference in the chromosome cycle. Univ. III. Biol Monogr. 1941;18(2):5-57

10. Clopton, R.E. Standard nomenclature and metrics of plane shapes for use in gregarine taxonomy.Comp Parasitol. 2004;71(130):140. doi: $10.1654 / 4151$

11. Yumnam I, Mohilal N. A new species of Quadruspinospora Sarkar and Chakravarty, 1969 (Apicomplexa: Conoidasida) from Orthopteran Insects of Manipur, India. Journal of Parasitic Diseases. 2017 Jun 1;41(2):313-7. 